\title{
Indirect contributions of global fires to surface ozone through ozone-vegetation feedback
}

\author{
Yadong Lei ${ }^{1,2}$, Xu Yue ${ }^{3}$, Hong Liao ${ }^{3}$, Lin Zhang ${ }^{4}$, Yang Yang ${ }^{3}$, Hao Zhou ${ }^{1,2}$, Chenguang Tian ${ }^{1,2}$, Cheng Gong ${ }^{2,5}$, \\ Yimian Ma ${ }^{1,2}$, Lan Gao ${ }^{1,2}$, and Yang $\mathrm{Cao}^{1,2}$ \\ ${ }^{1}$ Climate Change Research Center, Institute of Atmospheric Physics, Chinese Academy of Sciences, Beijing, 100029, China \\ ${ }^{2}$ University of Chinese Academy of Sciences, Beijing, 100029, China \\ ${ }^{3}$ Jiangsu Key Laboratory of Atmospheric Environment Monitoring and Pollution Control, Jiangsu Collaborative Innovation \\ Center of Atmospheric Environment and Equipment Technology, School of Environmental Science and Engineering, \\ Nanjing University of Information Science and Technology (NUIST), Nanjing, 210044, China \\ ${ }^{4}$ Laboratory for Climate and Ocean-Atmosphere Studies, Department of Atmospheric and Oceanic Sciences, \\ School of Physics, Peking University, Beijing, 100871, China \\ ${ }^{5}$ State Key Laboratory of Atmospheric Boundary Layer Physics and Atmospheric Chemistry (LAPC), \\ Institute of Atmospheric Physics, Chinese Academy of Sciences, Beijing, 100029, China
}

Correspondence: Xu Yue (yuexu@ nuist.edu.cn)

Received: 12 December 2020 - Discussion started: 13 January 2021

Revised: 2 July 2021 - Accepted: 2 July 2021 - Published: 3 August 2021

\begin{abstract}
Fire is an important source of ozone $\left(\mathrm{O}_{3}\right)$ precursors. The formation of surface $\mathrm{O}_{3}$ can cause damage to vegetation and reduce stomatal conductance. Such processes can feed back to inhibit dry deposition and indirectly enhance surface $\mathrm{O}_{3}$. Here, we apply a fully coupled chemistry-vegetation model to estimate the indirect contributions of global fires to surface $\mathrm{O}_{3}$ through $\mathrm{O}_{3}$-vegetation feedback during 2005-2012. Fire emissions directly increase the global annual mean $\mathrm{O}_{3}$ by $1.2 \mathrm{ppbv}(5.0 \%)$ with a maximum of $5.9 \mathrm{ppbv}(24.4 \%)$ averaged over central Africa by emitting a substantial number of precursors. Considering $\mathrm{O}_{3}$-vegetation feedback, fires additionally increase surface $\mathrm{O}_{3}$ by $0.5 \mathrm{ppbv}$ averaged over the Amazon in October, $0.3 \mathrm{ppbv}$ averaged over southern Asia in April, and $0.2 \mathrm{ppbv}$ averaged over central Africa in April. During extreme $\mathrm{O}_{3}$-vegetation interactions, such a feedback can rise to $>0.6 \mathrm{ppbv}$ in these fire-prone areas. Moreover, large ratios of indirect-to-direct fire $\mathrm{O}_{3}$ are found in eastern China $(3.7 \%)$ and the eastern US $(2.0 \%)$, where the high ambient $\mathrm{O}_{3}$ causes strong $\mathrm{O}_{3}$-vegetation interactions. With the likelihood of increasing fire risks in a warming climate, fires may promote surface $\mathrm{O}_{3}$ through both direct emissions and indirect chemistry-vegetation feedbacks. Such indirect en-
\end{abstract}

hancement will cause additional threats to public health and ecosystem productivity.

\section{Introduction}

Tropospheric ozone $\left(\mathrm{O}_{3}\right)$ is a toxic air pollutant with detrimental effects on vegetation (Yue and Unger, 2014; Juráň et al., 2021). Plant stomatal uptake of $\mathrm{O}_{3}$ decreases both chlorophyll and Rubisco contents and increases the deformity rate of chloroplasts (Booker et al., 2007; Akhtar et al., 2010; Inada et al., 2012), which further reduces the leaf area index (LAI) and gross primary productivity (GPP) of ecosystems (Karnosky et al., 2007; Ainsworth et al., 2012). Modeling studies estimated that $\mathrm{O}_{3}$ damage reduces global GPP by $1.5 \%-3.6 \%$ with regional maximum reductions of $8 \%-$ $20 \%$ over eastern US, western Europe, and eastern China (Yue and Unger, 2014; Lei et al., 2020; Zhu et al., 2021). In turn, vegetation damage also influences both the sources and sinks of $\mathrm{O}_{3}$ through biogeochemical and biogeophysical feedbacks (Curci et al., 2009; Heald and Geddes, 2016; Fitzky et al., 2019). The damaged vegetation decreases isoprene emissions and stomatal conductance (Wittig et al., 2009; Feng et al., 2019), which influence $\mathrm{O}_{3}$ production and 
dry deposition. Moreover, weakened leaf-level transpiration following $\mathrm{O}_{3}$ damage modulates meteorological parameters, such as surface air temperature and atmospheric relative humidity, leading to substantial biogeophysical feedbacks on surface $\mathrm{O}_{3}$ (Lombardozzi et al., 2012; Sadiq et al., 2017).

Interactions between air pollution and terrestrial ecosystems remain challenging due to limited process-based knowledge and the separate development of chemistry and vegetation models (He et al., 2020). At present, the feedbacks from $\mathrm{O}_{3}$-damaging vegetation on $\mathrm{O}_{3}$ have only been examined by four papers (Sadiq et al., 2017; Zhou et al., 2018; Gong et al., 2020; Zhu et al., 2021). Sadiq et al. (2017) implemented a parameterization of $\mathrm{O}_{3}$ vegetation damage into a climate model and quantified online $\mathrm{O}_{3}$-vegetation coupling. Simulations showed that surface $\mathrm{O}_{3}$ could be enhanced by up to 4 6 ppbv over Europe, North America, and China through comparable effects from biogeochemical (decreased dry deposition and increased isoprene emissions) and biogeophysical (changes in meteorological variables following reduced transpiration rate) feedbacks from $\mathrm{O}_{3}$-vegetation interactions. Similar conclusions were drawn by Zhu et al. (2021), who investigated the effects of $\mathrm{O}_{3}$-vegetation interaction in China using a two-way coupled land-atmosphere model. By including $\mathrm{O}_{3}$ damage to isoprene emissions in a fully coupled global chemistry-carbon-climate model, Gong et al. (2020) highlighted that such $\mathrm{O}_{3}$-vegetation positive feedbacks were mainly driven by reduced dry deposition following $\mathrm{O}_{3}$ damage to photosynthesis. Different from the three studies above, Zhou et al. (2018) implemented steady-state $\mathrm{O}_{3}$-induced LAI changes into the GEOS-Chem model and quantified only the influences of $\mathrm{O}_{3}$-vegetation biogeochemical feedbacks because the model is driven with prescribed meteorological fields. Results showed that $\mathrm{O}_{3}$-induced damage to LAI can enhance $\mathrm{O}_{3}$ by up to 3 ppbv in the tropics, eastern North America, and southern China through changes in dry deposition and isoprene emissions. All studies revealed a strong positive $\mathrm{O}_{3}$-vegetation feedback to surface $\mathrm{O}_{3}$, though the magnitudes are different due to discrepancies in $\mathrm{O}_{3}$-damaging schemes, as well as differences in the models.

Fire plays an important role in disturbing the terrestrial carbon budget (Bond-Lamberty et al., 2007; Amiro et al., 2009; Turetsky et al., 2011; Yue and Unger, 2018). Global fires directly emit $2-3 \mathrm{Pg}\left(1 \mathrm{Pg}=10^{15} \mathrm{~g}\right)$ carbon into the atmosphere every year (van der Werf et al., 2010). Moreover, fires contribute to the production of tropospheric $\mathrm{O}_{3}$ by emitting a substantial number of precursors (Cheng et al., 1998; Kita et al., 2000; Oltmans et al., 2010; Jaffe et al., 2013; Lu et al., 2016). Globally, fires account for 3\%-5\% of the total tropospheric $\mathrm{O}_{3}$ (Bey et al., 2001; Ziemke et al., 2009; Jaffe and Wigder, 2012). Regionally, especially in the Amazon and central Africa, fires can enhance surface $\mathrm{O}_{3}$ by $10-30 \mathrm{ppbv}$ through emissions of $\mathrm{NO}_{x}$ and volatile organic compounds (VOCs) during fire seasons (Yue and Unger, 2018; Pope et al., 2020). Over these regions, strong $\mathrm{O}_{3}$-vegetation inter- actions are expected because of high fire $\mathrm{O}_{3}$ concentrations and dense vegetation cover. Previous studies showed that fire $\mathrm{O}_{3}$ causes a large GPP reduction of $200-400 \mathrm{Tg} \mathrm{Cyr}^{-1}$ over the Amazon and central Africa (Pacifico et al., 2015; Yue and Unger, 2018). With likely increased wildfire activity due to global warming, surface $\mathrm{O}_{3}$ will be further enhanced by wildfires (Amiro et al., 2009; Balshi et al., 2009; Wang et al., 2016; Yue et al., 2017), leading to more severe $\mathrm{O}_{3}$ damage on vegetation. Although the feedback of vegetation damage on surface $\mathrm{O}_{3}$ has been comprehensively explored on global (Sadiq et al., 2017; Zhou et al., 2018; Gong et al., 2020) and regional (Zhu et al., 2021) scales, these studies all focused on $\mathrm{O}_{3}$-vegetation interactions from combined anthropogenic and natural sources. Therefore, quantification of the $\mathrm{O}_{3}$-vegetation interactions associated with fire emissions is very important for a comprehensive understanding of the effects of fires on surface $\mathrm{O}_{3}$.

Here, we apply a fully coupled chemistry-vegetation model (GEOS-Chem-Yale Interactive terrestrial Biosphere hereafter referred to as GC-YIBs) to examine the indirect contributions of fires to surface $\mathrm{O}_{3}$. Fire-induced $\mathrm{O}_{3}$ affects plant photosynthesis and stomatal conductance. In turn, predicted changes in LAI and canopy stomatal conductance influence both the sources and sinks of tropospheric $\mathrm{O}_{3}$. Such $\mathrm{O}_{3}$-vegetation interactions result in the additional enhancement of surface $\mathrm{O}_{3}$ caused by fire emissions (Fig. 1). Section 2 describes the GC-YIBs model and sensitivity experiments conducted in this study. Section 3 quantifies the feedbacks of fire-induced $\mathrm{O}_{3}$ vegetation damage on surface $\mathrm{O}_{3}$ concentrations. The last section summarizes the findings and discusses the uncertainties.

\section{Materials and methods}

\subsection{The GC-YIBs model}

GC-YIBs is a coupled chemistry-vegetation model developed by implementing the Yale Interactive terrestrial Biosphere (YIBs) model into GEOS-Chem version 12.0.0 (Lei et al., 2020). GEOS-Chem is a widely used global 3-D chemical transport model (CTM) for simulating atmospheric composition and air quality (Yue et al., 2015; Yan et al., 2018; David et al., 2019; Lu et al., 2019). This model uses a detailed $\mathrm{HO}_{x}-\mathrm{NO}_{x}-\mathrm{VOC}-\mathrm{O}_{3}$-halogen-aerosol tropospheric chemistry to simulate tropospheric $\mathrm{O}_{3}$ fluxes (Barret et al., 2016; Gong and Liao, 2019), while a simplified linearized Linoz chemistry mechanism is applied to simulate stratospheric $\mathrm{O}_{3}$ (McLinden et al., 2000). Aerosols simulated in GEOS-Chem include secondary inorganic aerosols, secondary organic aerosols, primary organic aerosols, black carbon, dust, and sea salt (Dang and Liao, 2019; Li et al., 2019). The gas-aerosol partitioning of the sulfate-nitrateammonium system is computed by the ISORROPIA v2.0 thermodynamic equilibrium model (Fountoukis and Nenes, 


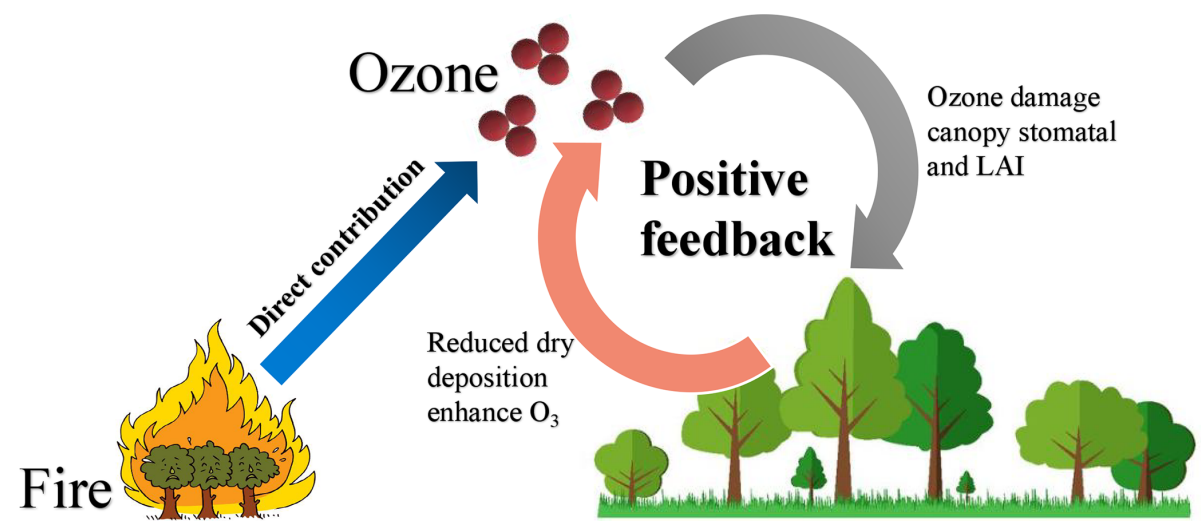

Figure 1. Diagram of the impacts of fires on surface $\mathrm{O}_{3}$ through direct emissions and $\mathrm{O}_{3}$-vegetation feedback.

2007). The atmospheric emissions from different sources, regions, and species on a user-defined grid are calculated through the online Harvard-NASA Emissions Component (HEMCO) module (Keller et al., 2014). HEMCO is highly customizable in that it can automatically combinate, overlay, and update emission inventories and scale factors specified by the users. In general, the GEOS-Chem model overestimates summer surface $\mathrm{O}_{3}$ concentrations in the eastern US and China (Zhang et al., 2011; Travis et al., 2016; Schiferl and Heald, 2018).

YIBs is a vegetation model designed to dynamically simulate the changes in LAI and tree height based on carbon assimilation, respiration, and allocation processes (Yue and Unger, 2015). The model computes carbon uptake for nine vegetation types, including evergreen needleleaf forest, deciduous broadleaf forest, evergreen broadleaf forest, shrubland, tundra, $\mathrm{C}_{3} / \mathrm{C}_{4}$ grasses, and $\mathrm{C}_{3} / \mathrm{C}_{4}$ crops. The canopy is divided into an adaptive number of layers (typically 216) for light stratification. The YIBs model applies a wellestablished Michaelis-Menten enzyme kinetics scheme to compute the leaf photosynthesis (Farquhar et al., 1980; Von Caemmerer and Farquhar, 1981), which is further upscaled to the canopy level by the separation of sunlit and shaded leaves (Spitters, 1986). The LAI and carbon allocation schemes are from the TRIFFID model (Clark et al., 2011). Previous studies have shown that the YIBs model has good performance in simulating the spatial pattern of and temporal variability in GPP and LAI based on site observations and satellite products (Yue and Unger, 2015, 2018).

The GC-YIBs model links atmospheric chemistry and vegetation in a two-way coupling. As a result, changes in chemical components or vegetation will simultaneously feed back to influence the other systems. In this study, the GCYIBs model is driven with the meteorological fields from the Modern-Era Retrospective analysis for Research and Applications, version 2 (MERRA2) with a horizontal resolution of $4^{\circ}$ latitude by $5^{\circ}$ longitude, as well as 47 vertical layers from the surface to $0.01 \mathrm{hPa}$. Within GC-YIBs, the onlinesimulated surface $\mathrm{O}_{3}$ in GEOS-Chem affects photosynthe- sis and canopy stomatal conductance; in turn, the onlinesimulated vegetation parameters, such as LAI and stomatal conductance, in YIBs affect both the sources and sinks of $\mathrm{O}_{3}$ by altering precursor emissions and dry deposition at the $1 \mathrm{~h}$ integration time step. An earlier study evaluated the GC-YIBs model and showed good performance in simulating surface $\mathrm{O}_{3}$, GPP, LAI, and $\mathrm{O}_{3}$ dry deposition (Lei et al., 2020).

\subsection{Scheme of $\mathrm{O}_{3}$ vegetation damage}

The GC-YIBs model calculates the impacts of $\mathrm{O}_{3}$ exposure on photosynthesis based on a semi-mechanistic scheme (Sitch et al., 2007):

$A^{\prime}=\alpha \cdot A$,

where $A^{\prime}$ and $A$ represent the $\mathrm{O}_{3}$-damaging and original leaf photosynthesis, respectively. The $\mathrm{O}_{3}$ damage factor is represented by $\alpha ; \mathrm{O}_{3}$ can cause damage to photosynthesis only if $\alpha<1$. The factor $\alpha$ is calculated as a function of excessive $\mathrm{O}_{3}$ flux and damaging sensitivity coefficient $(\beta)$ :

$\alpha=-\beta \cdot \max \left(F_{\mathrm{O}_{3}}-T_{\mathrm{O}_{3}}, 0\right)$.

The coefficient $\beta$ can have two values for each vegetation type (Table S1 in the Supplement), indicating low to high $\mathrm{O}_{3}$-damaging sensitivities (Sitch et al., 2007). $T_{\mathrm{O}_{3}}$ represents the $\mathrm{O}_{3}$ flux threshold, reflecting the $\mathrm{O}_{3}$ tolerance of different vegetation types. $F_{\mathrm{O}_{3}}$ represents the stomatal $\mathrm{O}_{3}$ flux and is calculated based on ambient $\left[\mathrm{O}_{3}\right]$, aerodynamic resistance $\left(r_{\mathrm{a}}\right)$, boundary layer resistance $\left(r_{\mathrm{b}}\right)$, and stomatal resistance $\left(r_{\mathrm{s}}\right)$ :

$F_{\mathrm{O}_{3}}=\frac{\left[\mathrm{O}_{3}\right]}{r_{\mathrm{a}}+r_{\mathrm{b}}+k \cdot r_{\mathrm{s}}^{\prime}}$.

Here $k$ represents the ratio of leaf resistance of $\mathrm{O}_{3}$ to leaf resistance of water vapor. Parameters $r_{\mathrm{a}}$ and $r_{\mathrm{b}}$ are calculated by the GEOS-Chem model. $\mathrm{O}_{3}$-damaging leaf photosynthesis $\left(A^{\prime}\right)$ is then integrated over all canopy layers to generate 
$\mathrm{O}_{3}$-damaging GPP:

$\mathrm{GPP}^{\prime}=\int_{0}^{\mathrm{LAI}} A^{\prime} \mathrm{d} L$.

The $\mathrm{O}_{3}$-damaging stomatal resistance $\left(r_{\mathrm{s}}^{\prime}\right)$ is calculated based on the model of Ball and Berry (Baldocchi et al., 1987):

$\frac{1}{r_{\mathrm{s}}^{\prime}}=g_{\mathrm{s}}^{\prime}=m \frac{A_{\mathrm{net}}^{\prime} \cdot \mathrm{RH}}{c_{\mathrm{s}}}+b$,

where $m$ and $b$ represent the slope and intercept of empirical fitting to the Ball-Berry stomatal conductance equation, respectively. $A_{\text {net }}^{\prime}$ represents $\mathrm{O}_{3}$-damaging net leaf photosynthesis, RH represents the relative humidity, and $c_{\mathrm{S}}$ is the ambient $\mathrm{CO}_{2}$ concentration. Previous studies have shown that this scheme within the framework of YIBs can reasonably capture the response of GPP and stomatal conductance to surface $\left[\mathrm{O}_{3}\right]$ based on hundreds of global observations (Yue et al., 2016; Yue and Unger, 2018).

\subsection{Fire emissions}

Fire INventory from the National Center for Atmospheric Research (FINN) version 1.5 is used by GC-YIBs to simulate fire-induced perturbations in $\mathrm{O}_{3}$. FINN provides daily global emissions of many chemical species from open biomass burning at a resolution of $1 \mathrm{~km}^{2}$ (Wiedinmyer et al., 2011). The inventory estimates fire locations and biomass burned using satellite observations of active fires and land cover, together with emission factors and fuel loadings. For each land type, emission factors for different gaseous and particulate species are taken from measurements (Andreae and Merlet, 2001; Andreae and Rosenfeld, 2008; Akagi et al., 2011). Daily fire emissions for 2002-2012 are available at https://www.acom.ucar.edu/Data/fire/, last access: 1 August 2021). In GC-YIBs, all biomass burning emissions occur in the atmospheric boundary layer. Such a configuration might slightly overestimate regional $\mathrm{O}_{3}$ formation as observations suggested $\sim 20 \%$ of fire plumes reached the height above the boundary layer (Val Martin et al., 2010) and consequently enhanced the surface $\mathrm{O}_{3}$ level in the downwind regions (Jaffe and Wigder, 2012). The FINN inventory has been widely used in regional and global chemical transport models (e.g., WRF-Chem and GEOS-Chem) to quantify the impacts of fires on air quality and weather (Jiang et al., 2012; Nuryanto, 2015; Vongruang et al., 2017; Brey et al., 2018; Watson et al., 2019).

\subsection{Site-level measurements}

Measurements of surface $\left[\mathrm{O}_{3}\right]$ in the US are provided by Air Quality System (AQS; https://www.epa.gov/aqs, last access: 1 August 2021), and those over Europe are provided by the European Monitoring and Evaluation Programme (EMEP; https://emep.int, last access: 1 August 2021). The observed
$\left[\mathrm{O}_{3}\right]$ at the Manaus (Brazil), Tanjung Malim (Malaysia), and Welgegund (South Africa) sites are from earlier studies (Ahamad et al., 2014; Laban et al., 2018; Pope et al., 2020).

\subsection{Model simulations}

In this study, eight simulations (Table 1) are performed to examine both the direct and indirect contributions of fires to surface $\mathrm{O}_{3}$. These simulations can be divided into two main groups:

1. CTRL_FIRE and CTRL_NOFIRE are the control runs using the same emissions except that the latter omits fire emissions. These runs calculate and output offline $\mathrm{O}_{3}$ damage, which decreases instantaneous leaf photosynthesis but does not feed back to affect plant growth and $\mathrm{O}_{3}$ dry deposition.

2. O3CPL_FIRE and O3CPL_NOFIRE are the sensitive experiments that consider online coupling between $\mathrm{O}_{3}$ and vegetation. These runs include online $\mathrm{O}_{3}$ damage to plant photosynthesis, which feeds back to affect both vegetation and air pollution. The two simulations apply the same emissions, except that the latter omits fire emissions.

For each of these four configurations, two runs are conducted with either high (HS) or low (LS) $\mathrm{O}_{3}$-damaging sensitivities. All simulations are performed from 2002 to 2012 using the GC-YIBs model driven by MERRA2 meteorological fields. The first 3 years are used as spinup, and the results of the last 8 years are analyzed. For the same configurations, the results from low and high $\mathrm{O}_{3}$-damaging sensitivities are averaged. The differences between CTRL_NOFIRE and O3CPL_NOFIRE represent the surface $\mathrm{O}_{3}$ enhancements through $\mathrm{O}_{3}$-vegetation feedback without fire emissions. The differences between CTRL_FIRE and CTRL_NOFIRE, named $\mathrm{O} 3 \mathrm{OFF}$, represent the direct contributions of fires to surface $\mathrm{O}_{3}$. The differences between O3CPL_FIRE and O3CPL_NOFIRE, named O3CPL, represent both direct and indirect contributions of fires to surface $\mathrm{O}_{3}$. The differences between $\mathrm{O} 3 \mathrm{CPL}$ and $\mathrm{O} 3 \mathrm{OFF}$ represent the indirect contributions of fires to surface $\mathrm{O}_{3}$ through $\mathrm{O}_{3}$-vegetation interactions. It should be noted that only biogeochemical feedbacks from $\mathrm{O}_{3}$ vegetation damage on surface $\mathrm{O}_{3}$ are considered in this study because GC-YIBs uses prescribed meteorology (MERRA2).

\section{Results}

\subsection{Model validation}

Simulated surface daily maximum $8 \mathrm{~h}$ average $\mathrm{O}_{3}$ concentrations (MDA $8\left[\mathrm{O}_{3}\right]$, short for $\left[\mathrm{O}_{3}\right]$ hereafter) are evaluated using measurements from the AQS and EMEP datasets over the period of 2005-2012 (Fig. 2). The model captures well the 
Table 1. Summary of simulations using the GC-YIBs model.

\begin{tabular}{llll}
\hline Name & Emissions & $\mathrm{O}_{3}$ damaging & $\mathrm{O}_{3}$ sensitivities \\
\hline CTRL_FIRE_HS & All including fires & Offline & High \\
CTRL_FIRE_LS & All including fires & Offline & Low \\
CTRL_NOFIRE_HS & All but without fires & Offline & High \\
CTRL_NOFIRE_LS & All but without fires & Offline & Low \\
O3CPL_FIRE_HS & All including fires & Online & High \\
O3CPL_FIRE_LS & All including fires & Online & Low \\
O3CPL_NOFIRE_HS & All but without fires & Online & High \\
O3CPL_NOFIRE_LS & All but without fires & Online & Low \\
\hline
\end{tabular}

observed spatial distribution of annual $\left[\mathrm{O}_{3}\right]$ in the US and $\mathrm{Eu}-$ rope, with a high correlation coefficient of $0.51(p<0.01)$. Although GC-YIBs overestimates the $\left[\mathrm{O}_{3}\right]$ in the eastern US while underestimating it in western Europe, the normalized mean bias (NMB) is only $4.0 \%$, with a root mean square error (RMSE) of $5.4 \mathrm{ppbv}$. Therefore, the simulated $\mathrm{O}_{3}$ vegetation damage in our study is slightly overestimated in the eastern US but underestimated in western Europe.

\subsection{Direct contributions of fires to $\mathrm{O}_{3}$}

Without fire emissions, the simulated global mean $\left[\mathrm{O}_{3}\right]$ is $23.9 \mathrm{ppbv}$, with a grid maximum of $63.7 \mathrm{ppbv}$ over the Beijing-Tianjin-Hebei region averaged for 2005-2012 (Fig. 3a). Most high $\left[\mathrm{O}_{3}\right]$ is distributed in the Northern Hemisphere, where anthropogenic emissions make the dominant contributions. The inclusion of fire emissions increases global annual $\left[\mathrm{O}_{3}\right]$ by an average of $1.2 \mathrm{ppbv}(5.0 \%)$. Regionally, the largest enhancement of $\left[\mathrm{O}_{3}\right]$ by $5.9 \mathrm{ppbv}$ $(24.4 \%)$ is averaged over central Africa, with smaller enhancements of $5.7 \mathrm{ppbv}(38.2 \%)$ averaged over the Amazon and $3.8 \mathrm{ppbv}(10.2 \%)$ averaged over southern Asia. Smaller enhancements of $1.1 \mathrm{ppbv}(2.2 \%), 0.9 \mathrm{ppbv}(2.1 \%)$, and $0.8 \mathrm{ppbv}(2.2 \%)$ are averaged respectively over eastern China, western Europe, and the eastern US (Fig. 3b). The predicted fire-induced enhancements in $\left[\mathrm{O}_{3}\right]$ agree well with the simulations using the same model but with fire emissions from the Global Fire Emissions Database (GFED) version 3 (Yue and Unger, 2018).

We further evaluated the model performance in simulating fire-induced $\Delta\left[\mathrm{O}_{3}\right]$ at three sites across biomass burning regions (Fig. S1 in the Supplement). Without fire emissions, the $\left[\mathrm{O}_{3}\right]$ is obviously underestimated with NMBs of $-25.5 \%$ at Tanjung Malim, $-53.6 \%$ at Manaus, and $-21.3 \%$ at Welgegund. As a comparison, simulations with fire emissions show NMBs in fire seasons of $-8.7 \%$ at Tanjung Malim, $-1.4 \%$ at Manaus, and $-15.1 \%$ at Welgegund, suggesting that $\mathrm{O}_{3}$ simulations were improved by including fire emissions.

\subsection{Fire-induced $\mathrm{O}_{3}$ damage to GPP}

Surface $\mathrm{O}_{3}$ causes strong damage to ecosystem productivity (Fig. 4). Without fire emissions, surface $\mathrm{O}_{3}$ reduces global annual GPP by $1.7 \%$ (3899.8 $\mathrm{TgCyr}^{-1}$; Fig. $4 \mathrm{a}$ and c). Regional maximum reductions of $10.9 \%\left(372.0 \mathrm{TgC}^{-1}\right)$, $6.1 \%\left(366.1 \mathrm{TgC} \mathrm{yr}^{-1}\right)$, and $4.9 \%\left(323.8 \mathrm{TgC} \mathrm{yr}^{-1}\right)$ are averaged respectively over eastern China, the eastern US, and western Europe; these reductions are attributed to the high ambient $\left[\mathrm{O}_{3}\right]$ level and the large stomatal conductance over these regions. The patterns of $\mathrm{O}_{3}$-induced GPP reductions agree with previous estimates using the same $\mathrm{O}_{3}$ damage schemes (Sitch et al., 2007; Yue and Unger, 2015). However, compared to simulations using another scheme (Lombardozzi et al., 2012; Zhou et al., 2018; Zhu et al., 2021), this study estimates smaller GPP reductions. Such a discrepancy indicates that there are large uncertainties in $\mathrm{O}_{3}$ vegetation damage schemes, and more observations should be developed to evaluate different schemes in future studies.

The inclusion of fire emissions causes additional GPP reductions. Globally, fire-induced $\Delta \mathrm{O}_{3}$ decreases annual GPP by $0.4 \%$ (1312.0 $\mathrm{TgCyr}^{-1}$; Fig. $4 \mathrm{~b}$ and d). Regionally, the largest GPP reduction of $1.4 \%\left(370.3 \mathrm{Tg} \mathrm{Cyr}^{-1}\right)$ is averaged over the Amazon due to the largest enhancement of $\left[\mathrm{O}_{3}\right]$ caused by fires. Furthermore, fire $\Delta\left[\mathrm{O}_{3}\right]$ causes additional annual GPP reductions of $1.3 \%\left(358.0 \mathrm{Tg} \mathrm{C} \mathrm{yr}^{-1}\right)$, averaged over central Africa, and $1.0 \%\left(77.1 \mathrm{Tg} \mathrm{Cyr}^{-1}\right)$, averaged over southern Asia. In contrast, limited damage is found in eastern China, western Europe, and the eastern US due to low fire $\Delta\left[\mathrm{O}_{3}\right]$. Following the changes in GPP, fire-induced $\mathrm{O}_{3}$ damage to LAI shows a regional maximum of $0.3 \%$ $0.7 \%$ in central Africa and a global reduction of $0.02 \%$ $0.5 \%$ (Fig. S2).

\subsection{Indirect contributions of fires to $\mathrm{O}_{3}$}

Vegetation parameters such as LAI and stomatal conductance play important roles in modulating surface $\left[\mathrm{O}_{3}\right]$. The $\mathrm{O}_{3}$ induced changes in these variables interactively feed back to alter local $\left[\mathrm{O}_{3}\right]$ (Fig. 5). Without fire emissions, the annual $\Delta\left[\mathrm{O}_{3}\right]$ from $\mathrm{O}_{3}$-vegetation interactions is limited in eastern China by 0.5 ppbv, the eastern US by 0.3 ppbv, and western 
(a) Simulated MDA8

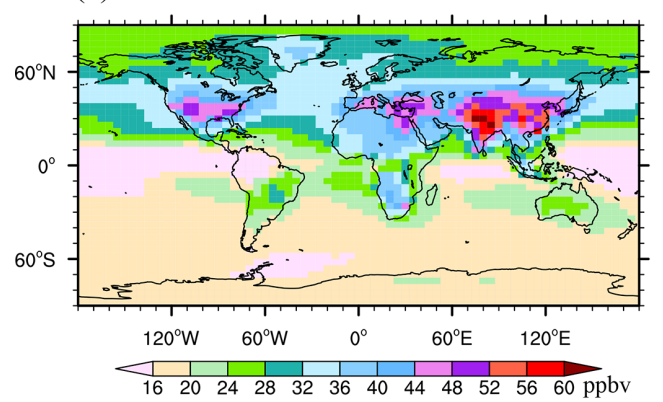

(b) Observed MDA8

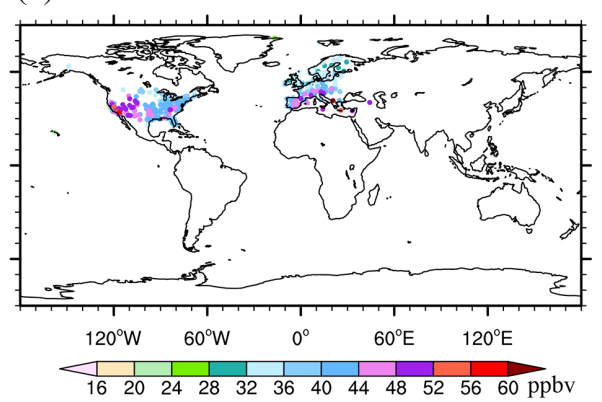

(c) Observation vs. Simulation

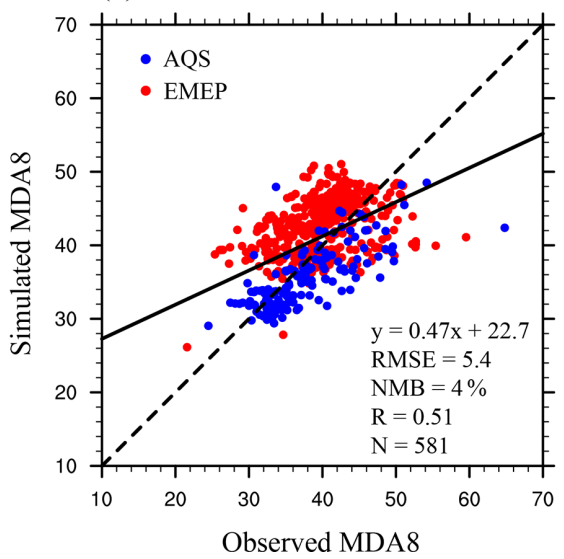

Figure 2. Spatial pattern of (a) simulated and (b) observed surface $\left[\mathrm{O}_{3}\right]$. (c) Scatter plot of surface $\left[\mathrm{O}_{3}\right]$ over measurements in two regions. The black line shows the linear regression between the observed and simulated $\left[\mathrm{O}_{3}\right]$. The regression fit, correlation coefficient $(R)$, root mean square error (RMSE), and normalized mean bias (NMB) are shown in the bottom panel with an indication of site numbers $(N)$ used for statistics.

(a) $\mathrm{O}_{3}$ from all emissions without fire

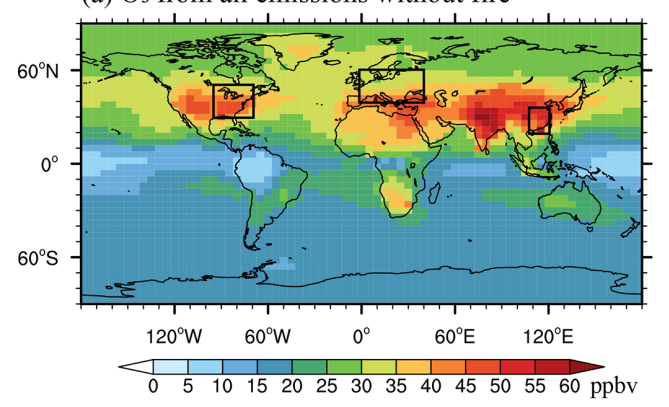

(b) $\Delta \mathrm{O}_{3}$ driven by fire emission

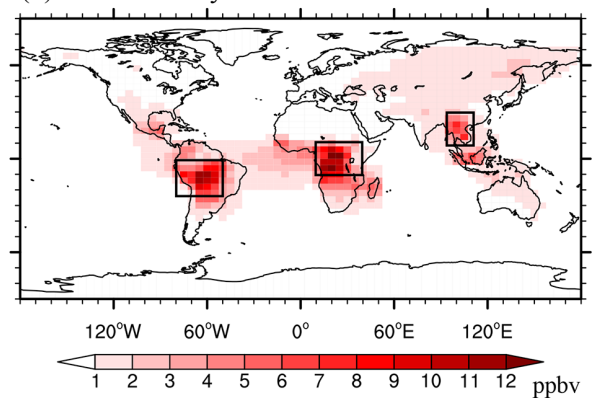

Figure 3. Annual surface $\left[\mathrm{O}_{3}\right]$ from (a) non-fire sources and (b) fire sources alone. The six subregions are marked with black boxes: eastern US (EUS; 30-50 $0^{\circ} \mathrm{N}, 95-70^{\circ} \mathrm{W}$ ), western Europe (WEU; 40-60 $\left.{ }^{\circ} \mathrm{N}, 0-40^{\circ} \mathrm{E}\right)$, eastern China (ECH; 20-35 $\left.{ }^{\circ} \mathrm{N}, 108-120^{\circ} \mathrm{E}\right)$, Amazon $(\mathrm{AMZ}$; $\left.25^{\circ} \mathrm{S}-0^{\circ}, 80-50^{\circ} \mathrm{W}\right)$, central Africa $\left(\mathrm{CAF} ; 10^{\circ} \mathrm{S}-10^{\circ} \mathrm{N}, 10-40^{\circ} \mathrm{E}\right)$, and southern Asia (SAS; $\left.10-30^{\circ} \mathrm{N}, 95-110^{\circ} \mathrm{E}\right)$.

Europe by $0.2 \mathrm{ppbv}$. The largest grid positive feedback of up to $0.8 \mathrm{ppbv}$ is found in the eastern US (Fig. $5 \mathrm{a}$ and c). Sensitivity experiments further show that such an enhancement of surface $\left[\mathrm{O}_{3}\right]$ mainly results from the inhibition of stomatal conductance following reduced photosynthesis because of $\mathrm{O}_{3}$ damage (Fig. S3a). Consequently, large $\Delta\left[\mathrm{O}_{3}\right]$ values (Fig. 5a and c) are collocated with areas enduring high levels of $\mathrm{O}_{3}$ vegetation damage (Fig. $4 \mathrm{a}$ and c). As a comparison, the feedback of LAI changes is generally small (Fig. S3b), which is mainly attributed to limited $\mathrm{O}_{3}$ damage to LAI (Fig. S2). The enhancement of $\left[\mathrm{O}_{3}\right]$ from fires causes additional feedback to the surface $\left[\mathrm{O}_{3}\right]$. The largest annual $\Delta\left[\mathrm{O}_{3}\right]$ of $0.13 \mathrm{ppbv}$ due to $\mathrm{O}_{3}$-vegetation feedback is averaged over the Amazon (Fig. 5b and d), where the highest GPP reductions by fire-induced $\mathrm{O}_{3}$ are predicted (Fig. $4 \mathrm{~b}$ and d). Such feedbacks additionally enhances local $\left[\mathrm{O}_{3}\right]$ by $0.12 \mathrm{ppbv}$, 
(a) High ozone damage to GPP (no fire)

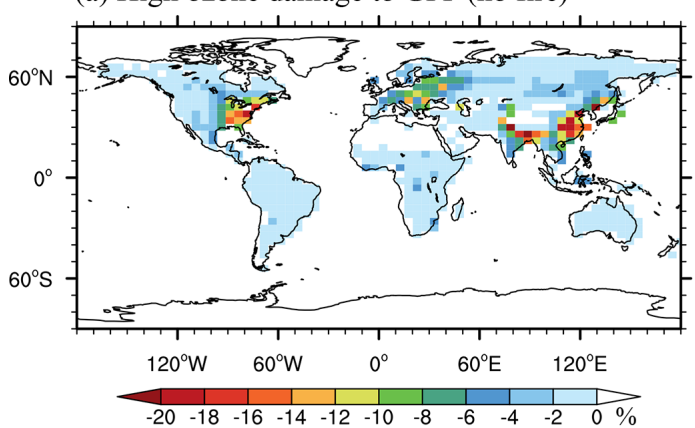

(c) Low ozone damage to GPP (no fire)

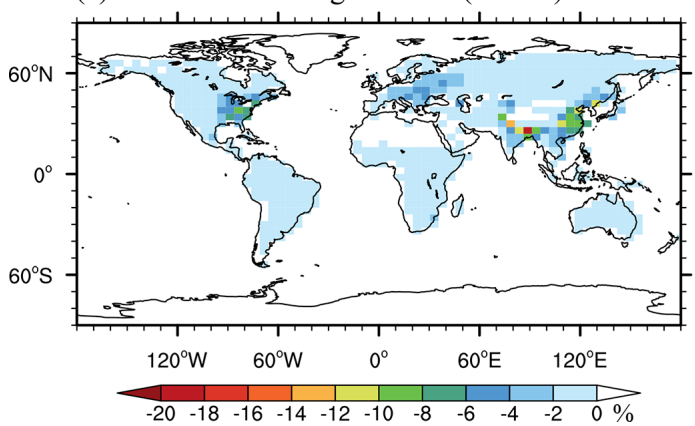

(b) High ozone damage to GPP (fire alone)

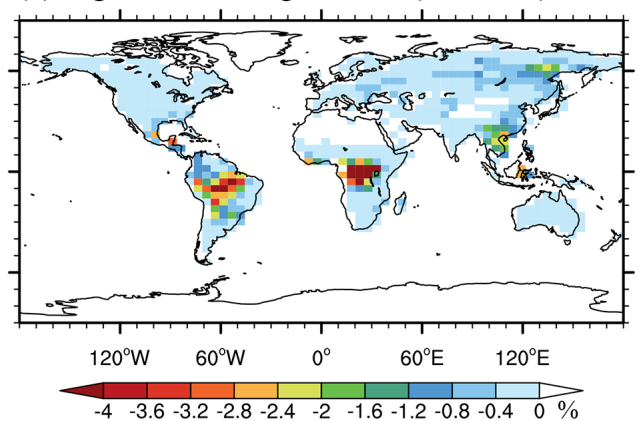

(d) Low ozone damage to GPP (fire alone)

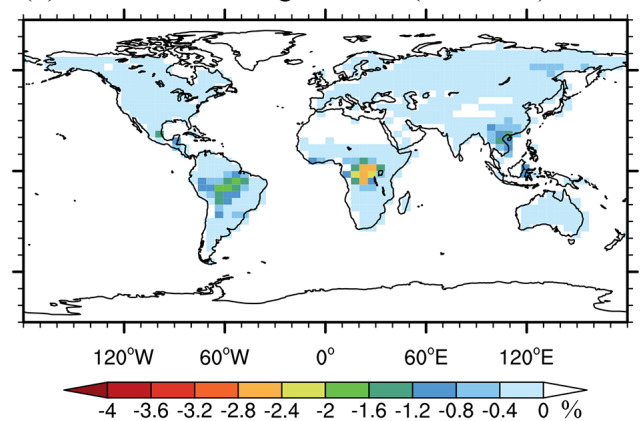

Figure 4. Annual percentage of reductions in GPP caused by $\mathrm{O}_{3}$ from (a, c) non-fire sources and (b, d) fire sources alone with (a, b) high and $(\mathbf{c}, \mathbf{d})$ low $\mathrm{O}_{3}$ sensitivities. Please note the differences in color scales.

(a) $\Delta \mathrm{O}_{3}$ driven by high ozone damage (no fire)

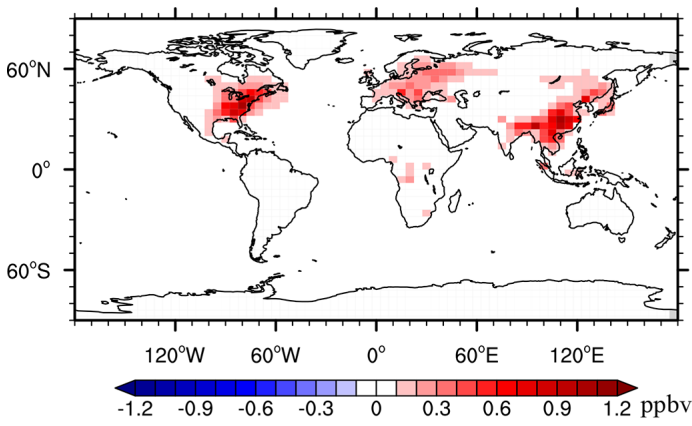

(c) $\Delta \mathrm{O}_{3}$ driven by low ozone damage (no fire)

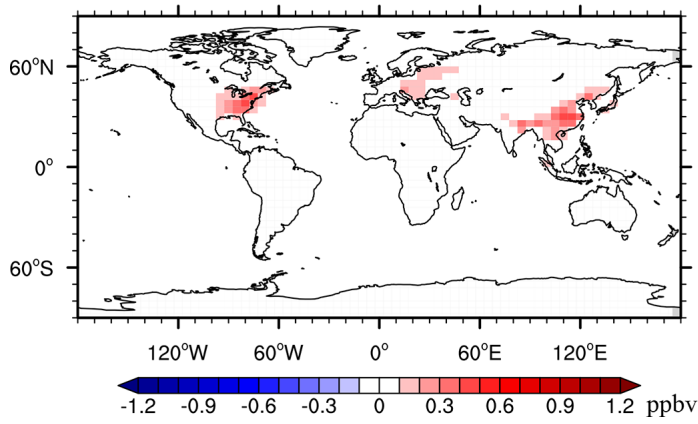

(b) $\Delta \mathrm{O}_{3}$ driven by high ozone damage (fire alone)

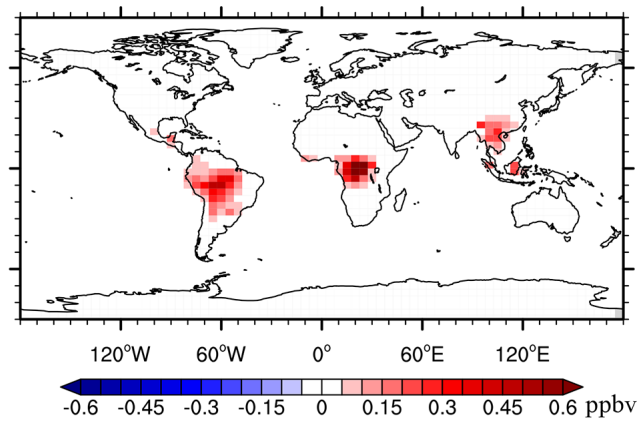

(d) $\Delta \mathrm{O}_{3}$ driven by low ozone damage (fire alone)

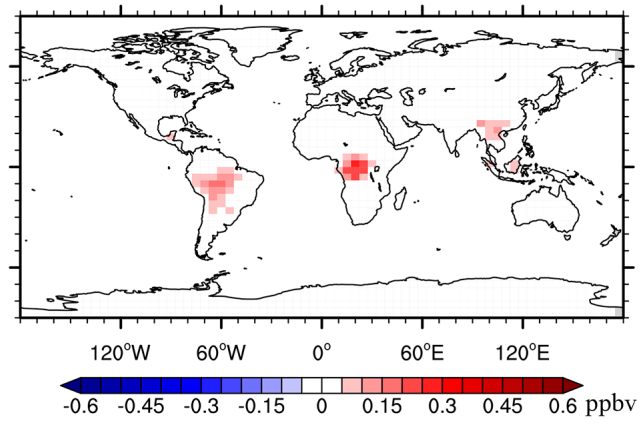

Figure 5. Annual feedback to surface $\mathrm{O}_{3}$ caused by $\mathrm{O}_{3}$ vegetation damage with (a, b) high and (c, d) low $\mathrm{O}_{3}$ sensitivities. Panels (a) and (c) represent feedback by $\mathrm{O}_{3}$ from non-fire sources, and panels (b) and (d) represent feedback by $\mathrm{O}_{3}$ from fire emissions alone. Please note the differences in color scales. 
averaged over central Africa, and $0.09 \mathrm{ppbv}$, averaged over southern Asia. However, limited $\mathrm{O}_{3}$-vegetation feedback is found in the eastern US, eastern China, and western Europe because of either low fire-induced $\Delta\left[\mathrm{O}_{3}\right]$ (Fig. 3b) or low $\Delta$ GPP (Fig. $4 \mathrm{~b}$ and d). The changes in $\mathrm{O}_{3}$ dry deposition velocity broadly match the pattern of $\mathrm{O}_{3}$-vegetation feedback (Fig. S4), suggesting that reduced dry deposition velocity due to $\mathrm{O}_{3}$-induced inhibition of stomatal conductance is the dominant driver for the enhanced surface $\left[\mathrm{O}_{3}\right]$.

Figure 6 shows seasonal variations in $\mathrm{O}_{3}$-vegetation feedback. Without fire emissions, $\mathrm{O}_{3}$-vegetation feedback in eastern China, the eastern US, and western Europe shows similar seasonal variations, increasing from January to July and then decreasing (Fig. 6a). For these regions, surface $\left[\mathrm{O}_{3}\right]$ and stomatal conductance reach maximums during the growth season (May-October), resulting in instantaneous $\mathrm{O}_{3}$ uptake. Therefore, $\mathrm{O}_{3}$-vegetation interactions are expected to be stronger during the growth season in the Northern Hemisphere. However, $\mathrm{O}_{3}$-vegetation feedback driven by fires in the Amazon and southern Asia reaches a maximum during August-December and February-June, respectively. Moreover, double peaks are shown in central Africa, with maximums during February-April and July-September (Fig. 6b). The distinct seasonal variations in biomass burning regions are attributed to fire emissions. At low latitudes, stomatal conductance shows limited seasonal variations. Therefore, $\mathrm{O}_{3}$-vegetation feedback driven by fires is mainly dependent on fire-induced $\Delta\left[\mathrm{O}_{3}\right]$.

Fire-induced $\mathrm{O}_{3}$ shows stronger interactions with vegetation under favorable meteorological conditions. We sort daily $\Delta\left[\mathrm{O}_{3}\right]$ from $\mathrm{O}_{3}$-vegetation feedback and calculate the average of $\Delta\left[\mathrm{O}_{3}\right]$ above the 95th percentile (Fig. S5). The spatial pattern of $\Delta\left[\mathrm{O}_{3}\right]$ during extreme $\mathrm{O}_{3}$-vegetation feedback is broadly consistent with that of the annual average, albeit with much stronger $\mathrm{O}_{3}$-vegetation feedback. Without fire emissions, $\mathrm{O}_{3}$-vegetation feedback enhances $\left[\mathrm{O}_{3}\right]$ by $2.0 \mathrm{ppbv}$ averaged over eastern China, 1.8 ppbv averaged over the eastern US, and $1.1 \mathrm{ppbv}$ averaged over western Europe (Fig. S5a and c). Fire emissions alone enhance $\left[\mathrm{O}_{3}\right]$ through $\mathrm{O}_{3}-$ vegetation interactions by $1.1 \mathrm{ppbv}$ averaged over the Amazon, $0.8 \mathrm{ppbv}$ averaged over southern Asia, and $0.6 \mathrm{ppbv}$ averaged over central Africa during extreme $\mathrm{O}_{3}$-vegetation feedback (Fig. S5b and d).

\subsection{Indirect vs. direct contributions of fires to $\mathrm{O}_{3}$}

We further compare the indirect and direct contributions of fire emissions to surface $\left[\mathrm{O}_{3}\right]$. Here, the direct contributions indicate $\Delta\left[\mathrm{O}_{3}\right]$ caused by fire emissions of chemical precursors, while the indirect contributions represent additional $\Delta\left[\mathrm{O}_{3}\right]$ from $\mathrm{O}_{3}$-vegetation interactions caused by fireinduced $\mathrm{O}_{3}$. Without fire emissions, $\mathrm{O}_{3}$-vegetation interactions cause an enhancement of $\left[\mathrm{O}_{3}\right]$ by $1.0 \%$ averaged over eastern China, $0.8 \%$ averaged over the eastern US, and $0.5 \%$ averaged over western Europe (Fig. 7a and c). Compared to non-fire sources, fire emissions cause larger relative perturbations in surface $\left[\mathrm{O}_{3}\right]$ through $\mathrm{O}_{3}$-vegetation interactions (Fig. $7 \mathrm{~b}$ and d). The ratios of indirect to direct annual $\Delta\left[\mathrm{O}_{3}\right]$ are $3.7 \%$ averaged over eastern China, $2.0 \%$ averaged over the eastern US, and $1.6 \%$ averaged over western Europe. For these regions, the absolute $\Delta\left[\mathrm{O}_{3}\right]$ from direct fire emissions is usually lower than 1 ppbv (Fig. $3 b$ ). However, the high level of background $\left[\mathrm{O}_{3}\right]$ (all sources except fire emissions; Fig. 3a) provides such a sensitive environment that the moderate increases in $\left[\mathrm{O}_{3}\right]$ from fires can cause significant feedback to regional surface $\left[\mathrm{O}_{3}\right]$ through vegetation damage. For fire-prone regions, the ratios of indirect to direct annual $\Delta\left[\mathrm{O}_{3}\right]$ are $2.6 \%$ averaged over southern Asia, $1.9 \%$ averaged over the eastern US, and $1.4 \%$ averaged over central Africa.

\subsection{Aggravated $\mathrm{O}_{3}$ damage to GPP through $\mathrm{O}_{3}$-vegetation feedback}

The additional $\mathrm{O}_{3}$ enhancement can exacerbate the damaging effects on vegetation. Without fire emissions, online $\mathrm{O}_{3}$ causes a global annual GPP reduction of $0.2 \%$ (299.6 $\mathrm{TgC} \mathrm{Cyr}^{-1}$; Fig. S6a and c) from the offline $\mathrm{O}_{3}$. Regionally, additional reductions are mainly found in eastern China, the eastern US, and western Europe, where GPP is further decreased by $27.1,40.8$, and $28.4 \mathrm{Tg} \mathrm{Cyr}^{-1}$, respectively. For fire emissions, the online fire-induced $\Delta \mathrm{O}_{3}$ results in a higher GPP reduction of $25.0 \mathrm{TgC}^{-1}$ averaged over the Amazon, $24.3 \mathrm{TgCyr}^{-1}$ averaged over central Africa, and $7.1 \mathrm{TgC}^{-1}$ averaged over southern Asia compared to the offline fire-induced $\Delta \mathrm{O}_{3}$ (Fig. S6b and d). Such spatial patterns are broadly consistent with $\Delta\left[\mathrm{O}_{3}\right]$ induced by $\mathrm{O}_{3}-$ vegetation feedback (Fig. 5).

\section{Conclusions and discussion}

Many studies have explored the direct contributions to surface $\mathrm{O}_{3}$ by fire emissions. However, the feedback of fireinduced $\mathrm{O}_{3}$ vegetation damage to surface $\left[\mathrm{O}_{3}\right]$ remains unquantified. In this study, we find that fire-induced $\mathrm{O}_{3}$ causes a positive feedback to surface $\left[\mathrm{O}_{3}\right]$ mainly because of the inhibition effects on stomatal conductance. Regionally, $\mathrm{O}_{3}-$ vegetation feedback driven by fires enhances surface annual $\left[\mathrm{O}_{3}\right]$ by $0.13 \mathrm{ppbv}$ averaged over the Amazon, $0.12 \mathrm{ppbv}$ averaged over central Africa, and $0.09 \mathrm{ppbv}$ averaged over southern Asia. Such feedbacks exhibit large seasonal variations, with the maximums of $0.5 \mathrm{ppbv}$ averaged over the Amazon in October, 0.3 ppbv averaged over southern Asia in April, and 0.2 ppbv averaged over central Africa in April. During extreme $\mathrm{O}_{3}$-vegetation interactions, the feedback can rise to $>0.6 \mathrm{ppbv}$ in these fire-prone areas. Although direct formations of $\mathrm{O}_{3}$ from fires are limited in eastern China and the eastern US, the feedback of $\mathrm{O}_{3}$-vegetation coupling results in the additional enhancement of surface $\left[\mathrm{O}_{3}\right]$ by $3.7 \%$ 
(a) Emissions without fire

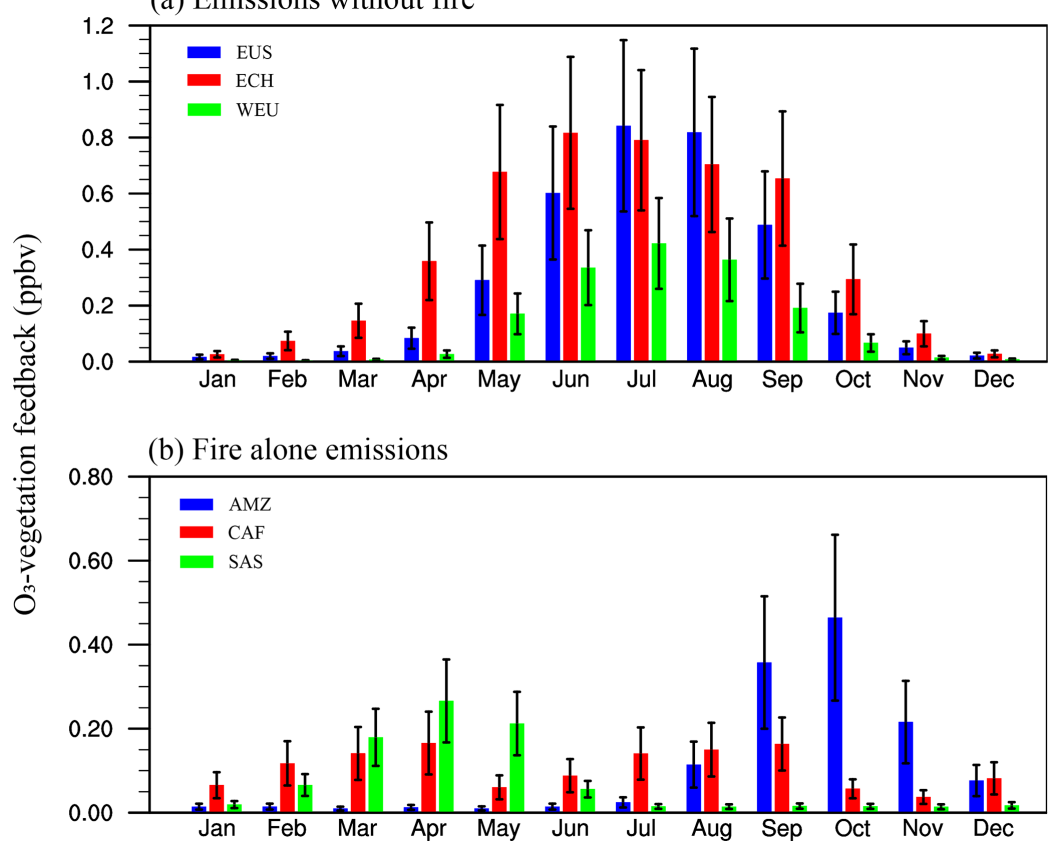

Figure 6. Seasonal variations in $\mathrm{O}_{3}$-vegetation feedback driven by (a) non-fire sources and (b) fire sources alone. The blue, red, and green bars in (a) represent the $\mathrm{O}_{3}$-vegetation feedback in eastern US (EUS), eastern China (ECH), and western Europe (WEU), respectively. The blue, red, and green bars in (b) represent the $\mathrm{O}_{3}$-vegetation feedback in the Amazon (AMZ), central Africa (CAF), and southern Asia (SAS), respectively. The error bars represent low to high $\mathrm{O}_{3}$-damaging sensitivities.

(a) Percentages of ozone-vegetation feedback with high ozone damage (no fire)

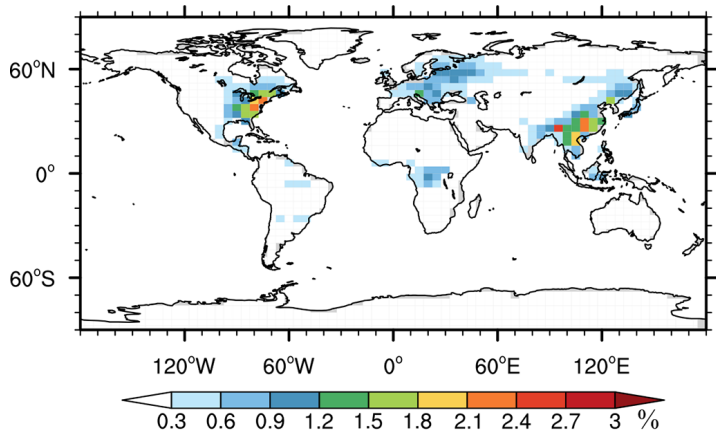

(c) Percentages of ozone-vegetation feedback with low ozone damage (no fire)

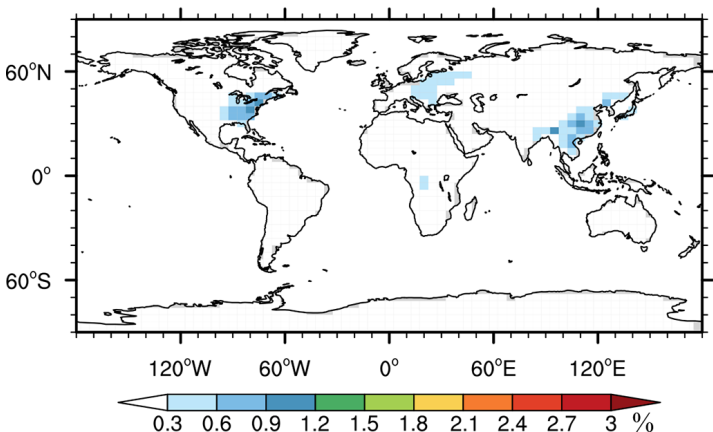

(b) Ratios of indirect effect to direct effect with high ozone damage (fire alone)

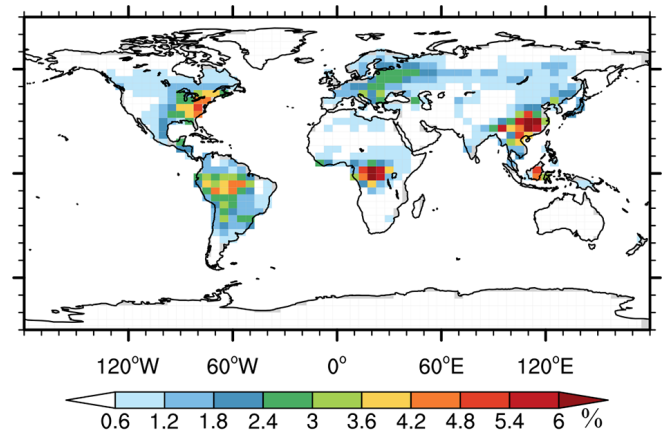

(d) Ratios of indirect effect to direct effect with low ozone damage (fire alone)

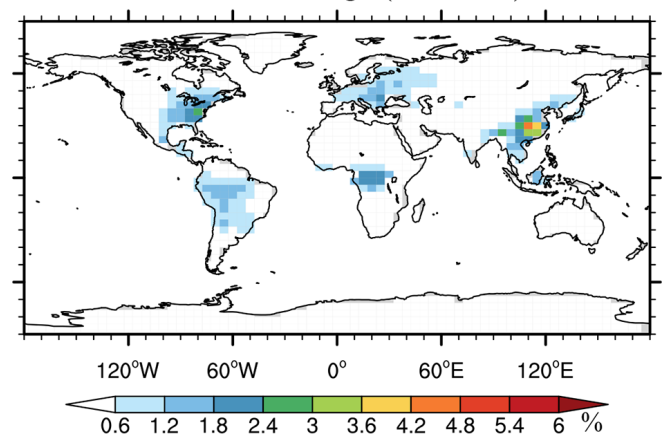

Figure 7. Annal ratios of indirect $\Delta\left[\mathrm{O}_{3}\right]$ to ambient $\left[\mathrm{O}_{3}\right]$ from $(\mathbf{a}, \mathbf{c})$ non-fire emissions and the ratios of indirect to direct $\Delta\left[\mathrm{O}_{3}\right]$ from $(\mathbf{b}, \mathbf{d})$ fire emissions alone with $(\mathbf{a}, \mathbf{b})$ high and $(\mathbf{c}, \mathbf{d})$ low $\mathrm{O}_{3}$-damaging sensitivities. Please note the differences in color scales. 
and $2.0 \%$ on the fire-induced $\Delta\left[\mathrm{O}_{3}\right]$. Such large ratios in these regions are attributed to the high level of ambient $\left[\mathrm{O}_{3}\right]$ that provides a sensitive environment in which moderate increases in $\left[\mathrm{O}_{3}\right]$ from fires can cause large indirect contributions to regional $\left[\mathrm{O}_{3}\right]$ through vegetation damage.

Some uncertainties may affect the conclusions of this study. (i) The GC-YIBs simulations do not consider the direct fire damage to vegetation and the consequent long-term recovery of forests. In our study, we focus only on the feedbacks of fire-induced $\mathrm{O}_{3}$-vegetation interactions to surface $\mathrm{O}_{3}$. (ii) Fires can decrease VOC emissions from biogenic sources by damaging vegetation directly. However, compared to the VOCs emitted by fires, the VOC loss from burned vegetation is generally smaller (Fig. S7). Therefore, the influence of reduced VOCs from vegetation loss on surface $\left[\mathrm{O}_{3}\right]$ can be ignored. (iii) There is evidence that $\mathrm{O}_{3}$ exposure may cause "sluggishness" that delays the stomatal responses to $\mathrm{O}_{3}$ damage (Huntingford et al., 2018). However, we do not include sluggishness in our scheme because its net impacts on stomatal conductance remain uncertain. For example, observations found that the increased shortterm water loss (delayed stomatal responses) may be offset by the decreased long-term water loss (lower steady-state stomatal conductance) with the stomatal sluggishness (Paoletti et al., 2019). (iv) We employed a model resolution of $4^{\circ} \times 5^{\circ}$ due to the limitations in computational resources. We performed a 1-year sensitivity simulation at a $2^{\circ} \times 2.5^{\circ}$ resolution. The comparisons show that fire-induced direct $\mathrm{O}_{3}$ enhancement is very similar between the simulations at low and high resolutions, although the former runs predict slightly higher changes in $\left[\mathrm{O}_{3}\right]$ than the latter (Fig. S8). (v) Different biomass burning datasets may affect the estimated $\mathrm{O}_{3}-$ vegetation feedback in our study. At present, the FINNv1.5 and GFEDv4.1 inventories are available in the public release of GEOS-Chem v12.0.0. Compared with the FINNv1.5 inventory, simulations using the GFEDv4.1 inventory predict a lower $\mathrm{O}_{3}$-vegetation feedback in the Amazon (Fig. S9a) and southern Asia (Fig. S9c) but a higher $\mathrm{O}_{3}$-vegetation feedback in central Africa (Fig. S9b).

Despite these uncertainties, we present the first estimate of $\mathrm{O}_{3}$ enhancement by fire emissions through $\mathrm{O}_{3}$-vegetation interactions. Such an enhancement is not limited to fireprone regions but is also significant over downwind areas with high ambient $\left[\mathrm{O}_{3}\right]$ levels. Although the absolute perturbations may be moderate for the whole fire season, $\mathrm{O}_{3}-$ vegetation interactions can largely increase surface $\mathrm{O}_{3}$ during extreme $\mathrm{O}_{3}$-vegetation interactions, leading to additional threats to public health and ecosystem productivity.

Data availability. The site-level $\left[\mathrm{O}_{3}\right]$ in the US can be download from AQS (https://www.epa.gov/aqs, AQS, 2021). The sitelevel $\left[\mathrm{O}_{3}\right]$ in Europe can be download from EMEP (https://emep. int, EMEP, 2021). The observed $\left[\mathrm{O}_{3}\right]$ at the Manaus, Tanjung Malim, and Welgegund sites are from earlier studies (Ahamad et al., 2014, https://doi.org/10.1016/j.atmosres.2014.01.003; Laban et al., 2018, https://doi.org/10.5194/acp-18-15491-2018; Pope et al., 2020, https://doi.org/10.1029/2019GL084143). The GC-YIBs simulation results are available from the corresponding authors on request.

Supplement. The supplement related to this article is available online at: https://doi.org/10.5194/acp-21-11531-2021-supplement.

Author contributions. XY conceived the study. YL conducted the model simulations. YL and XY were responsible for results analysis. HL, LZ, and YY revised and improved the manuscript. HZ, CT, and CG helped prepare model input. YM, LG, and YC helped prepare the observation dataset.

Competing interests. The authors declare that they have no conflict of interest.

Disclaimer. Publisher's note: Copernicus Publications remains neutral with regard to jurisdictional claims in published maps and institutional affiliations.

Acknowledgements. The authors acknowledge the United States Environmental Protection Agency and European Monitoring and Evaluation Programme for making their data publicly available.

Financial support. This research has been supported by the Jiangsu Science Fund for Distinguished Young Scholars (grant no. BK20200040) and the National Natural Science Foundation of China (grant no. 41975155).

Review statement. This paper was edited by Manvendra K. Dubey and reviewed by two anonymous referees.

\section{References}

Ahamad, F., Latif, M. T., Tang, R., Juneng, L., Dominick, D., and Juahir, H.: Variation of surface ozone exceedance around Klang Valley, Malaysia, Atmos. Res., 139, 116-127, https://doi.org/10.1016/j.atmosres.2014.01.003, 2014.

Ainsworth, E. A., Yendrek, C. R., Sitch, S., Collins, W. J., and Emberson, L. D.: The Effects of Tropospheric Ozone on Net Primary Productivity and Implications for Climate Change, Annu. Rev. Plant. Biol., 63, 637-661, https://doi.org/10.1146/annurevarplant-042110-103829, 2012.

Akagi, S. K., Yokelson, R. J., Wiedinmyer, C., Alvarado, M. J., Reid, J. S., Karl, T., Crounse, J. D., and Wennberg, P. O.: Emission factors for open and domestic biomass burning for use in atmospheric models, Atmos. Chem. Phys., 11, 4039-4072, https://doi.org/10.5194/acp-11-4039-2011, 2011. 
Akhtar, N., Yamaguchi, M., Inada, H., Hoshino, D., Kondo, T., and Izuta, T.: Effects of ozone on growth, yield and leaf gas exchange rates of two Bangladeshi cultivars of wheat (Triticum aestivum L.), Environ. Pollut., 158, 1763-1767, https://doi.org/10.1016/j.envpol.2009.11.011, 2010.

Amiro, B. D., Cantin, A., Flannigan, M. D., and de Groot, W. J.: Future emissions from Canadian boreal forest fires, Can. J. Forest. Res., 39, 383-395, https://doi.org/10.1139/X08-154, 2009.

Andreae, M. and Rosenfeld, D.: Aerosol-cloud-precipitation interactions. Part 1. The nature and sources of cloud-active aerosols, Earth-Sci. Rev., 89, 13-41, 2008.

Andreae, M. O. and Merlet, P.: Emission of trace gases and aerosols from biomass burning, Global Biogeochem. Cy., 15, 955-966, 2001.

AQS: Ambient air pollution data from the Air Quality System, United States Environmental Protection Agency, available at: https://www.epa.gov/aqs, last access: 1 August 2021.

Baldocchi, D. D., Hicks, B. B., and Camara, P.: A Canopy StomatalResistance Model for Gaseous Deposition to Vegetated Surfaces, Atmos. Environ., 21, 91-101, https://doi.org/10.1016/00046981(87)90274-5, 1987.

Balshi, M. S., McGUIRE, A. D., Duffy, P., Flannigan, M., Walsh, J., and Melillo, J.: Assessing the response of area burned to changing climate in western boreal North America using a Multivariate Adaptive Regression Splines (MARS) approach, Glob. Change Biol., 15, 578-600, https://doi.org/10.1111/j.13652486.2008.01679.x, 2009.

Barret, B., Sauvage, B., Bennouna, Y., and Le Flochmoen, E.: Upper-tropospheric $\mathrm{CO}$ and $\mathrm{O}_{3}$ budget during the Asian summer monsoon, Atmos. Chem. Phys., 16, 9129-9147, https://doi.org/10.5194/acp-16-9129-2016, 2016.

Bey, I., Jacob, D. J., Logan, J. A., and Yantosca, R. M.: Asian chemical outflow to the Pacific in spring: Origins, pathways, and budgets, J. Geophys. Res.-Atmos., 106, 23097-23113, https://doi.org/10.1029/2001jd000806, 2001.

Bond-Lamberty, B., Peckham, S. D., Ahl, D. E., and Gower, S. T.: Fire as the dominant driver of central Canadian boreal forest carbon balance, Nature, 450, 89-92, https://doi.org/10.1038/nature06272, 2007.

Booker, F. L., Burkey, K. O., Pursley, W. A., and Heagle, A. S.: Elevated carbon dioxide and ozone effects on peanut: I. Gasexchange, biomass, and leaf chemistry, Crop. Sci., 47, 14751487, https://doi.org/10.2135/cropsci2006.08.0537, 2007.

Brey, S. J., Barnes, E. A., Pierce, J. R., Wiedinmyer, C., and Fischer, E. V.: Environmental Conditions, Ignition Type, and Air Quality Impacts of Wildfires in the Southeastern and Western United States, Earths Future, 6, 1442-1456, 2018

Cheng, L., McDonald, K. M., Angle, R. P., and Sandhu, H. S.: Forest fire enhanced photochemical air pollution. A case study, Atmos. Environ., 32, 673-681, https://doi.org/10.1016/S13522310(97)00319-1, 1998.

Clark, D. B., Mercado, L. M., Sitch, S., Jones, C. D., Gedney, N., Best, M. J., Pryor, M., Rooney, G. G., Essery, R. L. H., Blyth, E., Boucher, O., Harding, R. J., Huntingford, C., and Cox, P. M.: The Joint UK Land Environment Simulator (JULES), model description - Part 2: Carbon fluxes and vegetation dynamics, Geosci. Model Dev., 4, 701-722, https://doi.org/10.5194/gmd-4701-2011, 2011.
Curci, G., Beekmann, M., Vautard, R., Smiatek, G., Steinbrecher, R., Theloke, J., and Friedrich, R.: Modelling study of the impact of isoprene and terpene biogenic emissions on European ozone levels, Atmos. Environ., 43, 1444-1455, https://doi.org/10.1016/j.atmosenv.2008.02.070, 2009.

Dang, R. and Liao, H.: Severe winter haze days in the BeijingTianjin-Hebei region from 1985 to 2017 and the roles of anthropogenic emissions and meteorology, Atmos. Chem. Phys., 19, 10801-10816, https://doi.org/10.5194/acp-19-10801-2019, 2019.

David, L. M., Ravishankara, A., Brewer, J. F., Sauvage, B., Thouret, V., Venkataramani, S., and Sinha, V.: Tropospheric ozone over the Indian subcontinent from 2000 to 2015: Data set and simulation using GEOS-Chem chemical transport model, Atmos. Environ., 219, 117039 , https://doi.org/10.1016/j.atmosenv.2019.117039, 2019.

EMEP: The air quality monitoring network from European Monitoring and Evaluation Programme, available at: https://emep.int, last access: 1 August 2021.

Farquhar, G. D., von Caemmerer, S., and Berry, J. A.: A biochemical model of photosynthetic $\mathrm{CO}_{2}$ assimilation in leaves of $\mathrm{C}_{3}$ species, Planta, 149, 78-90, 1980.

Feng, Z. Z., Yuan, X. Y., Fares, S., Loreto, F., Li, P., Hoshika, Y., and Paoletti, E.: Isoprene is more affected by climate drivers than monoterpenes: A meta-analytic review on plant isoprenoid emissions, Plant Cell Environ., 42, 1939-1949, https://doi.org/10.1111/pce.13535, 2019.

Fitzky, A. C., Sandén, H., Karl, T., Fares, S., Calfapietra, C., Grote, R., Saunier, A., and Rewald, B.: The interplay between ozone and urban vegetation-BVOC emissions, ozone deposition and tree ecophysiology, Frontiers in Forests and Global Change, 2, 50, https://doi.org/10.3389/ffgc.2019.00050, 2019.

Fountoukis, C. and Nenes, A.: ISORROPIA II: a computationally efficient thermodynamic equilibrium model for $\mathrm{K}^{+}-\mathrm{Ca}^{2+}-\mathrm{Mg}^{2+}-\mathrm{NH}_{4}^{+}-\mathrm{Na}^{+}-\mathrm{SO}_{4}^{2-}-\mathrm{NO}_{3}^{-}-\mathrm{Cl}^{-}-\mathrm{H}_{2} \mathrm{O}$ aerosols, Atmos. Chem. Phys., 7, 4639-4659, https://doi.org/10.5194/acp-7-4639-2007, 2007.

Gong, C. and Liao, H.: A typical weather pattern for ozone pollution events in North China, Atmos. Chem. Phys., 19, 13725-13740, https://doi.org/10.5194/acp-19-13725-2019, 2019.

Gong, C., Lei, Y., Ma, Y., Yue, X., and Liao, H.: Ozonevegetation feedback through dry deposition and isoprene emissions in a global chemistry-carbon-climate model, Atmos. Chem. Phys., 20, 3841-3857, https://doi.org/10.5194/acp-203841-2020, 2020.

He, C., Clifton, O., Felker-Quinn, E., Fulgham, S. R., Juncosa Calahorrano, J. F., Lombardozzi, D., Purser, G., Riches, M., Schwantes, R., Tang, W., Poulter, B., and Steiner, A. L.: Interactions between Air Pollution and Terrestrial Ecosystems: Perspectives on Challenges and Future Directions, B. Am. Meteorol. Soc., 102, E525-E538, https://doi.org/10.1175/BAMS-D20-0066.1, 2020.

Heald, C. L. and Geddes, J. A.: The impact of historical land use change from 1850 to 2000 on secondary particulate matter and ozone, Atmos. Chem. Phys., 16, 14997-15010, https://doi.org/10.5194/acp-16-14997-2016, 2016.

Huntingford, C., Oliver, R. J., Mercado, L. M., and Sitch, S.: Technical note: A simple theoretical model framework to describe plant stomatal "sluggishness" in response to ele- 
vated ozone concentrations, Biogeosciences, 15, 5415-5422, https://doi.org/10.5194/bg-15-5415-2018, 2018.

Inada, H., Kondo, T., Akhtar, N., Hoshino, D., Yamaguchi, M., and Izuta, T.: Relationship between cultivar difference in the sensitivity of net photosynthesis to ozone and reactive oxygen species scavenging system in Japanese winter wheat (Triticum aestivum), Physiol. Plantarum, 146, 217-227, https://doi.org/10.1111/j.1399-3054.2012.01618.x, 2012.

Jaffe, D. A. and Wigder, N. L.: Ozone production from wildfires: A critical review, Atmos. Environ., 51, 1-10, https://doi.org/10.1016/j.atmosenv.2011.11.063, 2012.

Jaffe, D. A., Wigder, N., Downey, N., Pfister, G., Boynard, A., and Reid, S. B.: Impact of wildfires on ozone exceptional events in the Western US, Environ. Sci. Technol., 47, 11065-11072, https://doi.org/10.1021/es402164f, 2013.

Jiang, X. Y., Wiedinmyer, C., and Carlton, A. G.: Aerosols from Fires: An Examination of the Effects on Ozone Photochemistry in the Western United States, Environ. Sci. Technol., 46, 1187811886, https://doi.org/10.1021/es301541k, 2012.

Juráň, S., Grace, J., and Urban, O.: Temporal Changes in Ozone Concentrations and Their Impact on Vegetation, Atmosphere, 12, 82, https://doi.org/10.3390/atmos12010082, 2021.

Karnosky, D. F., Skelly, J. M., Percy, K. E., and Chappelka, A. H.: Perspectives regarding 50 years of research on effects of tropospheric ozone air pollution on US forests, Environ. Pollut., 147, 489-506, https://doi.org/10.1016/j.envpol.2006.08.043, 2007.

Keller, C. A., Long, M. S., Yantosca, R. M., Da Silva, A. M., Pawson, S., and Jacob, D. J.: HEMCO v1.0: a versatile, ESMF-compliant component for calculating emissions in atmospheric models, Geosci. Model Dev., 7, 1409-1417, https://doi.org/10.5194/gmd-7-1409-2014, 2014.

Kita, K., Fujiwara, M., and Kawakami, S.: Total ozone increase associated with forest fires over the Indonesian region and its relation to the El Nino-Southern oscillation, Atmos. Environ., 34, 2681-2690, https://doi.org/10.1016/S1352-2310(99)005221, 2000.

Laban, T. L., van Zyl, P. G., Beukes, J. P., Vakkari, V., Jaars, K., Borduas-Dedekind, N., Josipovic, M., Thompson, A. M., Kulmala, M., and Laakso, L.: Seasonal influences on surface ozone variability in continental South Africa and implications for air quality, Atmos. Chem. Phys., 18, 15491-15514, https://doi.org/10.5194/acp-18-15491-2018, 2018.

Lei, Y., Yue, X., Liao, H., Gong, C., and Zhang, L.: Implementation of Yale Interactive terrestrial Biosphere model v1.0 into GEOS-Chem v12.0.0: a tool for biospherechemistry interactions, Geosci. Model Dev., 13, 1137-1153, https://doi.org/10.5194/gmd-13-1137-2020, 2020.

Li, S., Chen, L., Huang, G., Lin, J., Yan, Y., Ni, R., Huo, Y., Wang, J., Liu, M., and Weng, H.: Retrieval of surface $\mathrm{PM}_{2.5}$ mass concentrations over North China using visibility measurements and GEOS-Chem simulations, Atmos. Environ., 22, 117121, https://doi.org/10.1016/j.atmosenv.2019.117121, 2019.

Lombardozzi, D., Levis, S., Bonan, G., and Sparks, J. P.: Predicting photosynthesis and transpiration responses to ozone: decoupling modeled photosynthesis and stomatal conductance, Biogeosciences, 9, 3113-3130, https://doi.org/10.5194/bg-9-31132012, 2012.

Lu, X., Zhang, L., Yue, X., Zhang, J., Jaffe, D. A., Stohl, A., Zhao, Y., and Shao, J.: Wildfire influences on the variabil- ity and trend of summer surface ozone in the mountainous western United States, Atmos. Chem. Phys., 16, 14687-14702, https://doi.org/10.5194/acp-16-14687-2016, 2016.

Lu, X., Zhang, L., Chen, Y., Zhou, M., Zheng, B., Li, K., Liu, Y., Lin, J., Fu, T.-M., and Zhang, Q.: Exploring 2016-2017 surface ozone pollution over China: source contributions and meteorological influences, Atmos. Chem. Phys., 19, 8339-8361, https://doi.org/10.5194/acp-19-8339-2019, 2019.

McLinden, C., Olsen, S., Hannegan, B., Wild, O., Prather, M., and Sundet, J.: Stratospheric ozone in 3-D models: A simple chemistry and the cross-tropopause flux, J. Geophys. Res.-Atmos., 105, 14653-14665, 2000.

Nuryanto, D. E.: Simulation of forest fires smoke using WRF-Chem model with FINN fire emissions in Sumatera, Procedia Environ. Sci., 24, 65-69, https://doi.org/10.1016/j.proenv.2015.03.010, 2015.

Oltmans, S. J., Lefohn, A. S., Harris, J. M., Tarasick, D. W., Thompson, A. M., Wernli, H., Johnson, B. J., Novelli, P. C., Montzka, S. A., Ray, J. D., Patrick, L. C., Sweeney, C., Jefferson, A., Dann, T., Davies, J., Shapiro, M., and Holben, B. N.: Enhanced ozone over western North America from biomass burning in Eurasia during April 2008 as seen in surface and profile observations, Atmos. Environ., 44, 4497-4509, https://doi.org/10.1016/j.atmosenv.2010.07.004, 2010.

Pacifico, F., Folberth, G. A., Sitch, S., Haywood, J. M., Rizzo, L. V., Malavelle, F. F., and Artaxo, P.: Biomass burning related ozone damage on vegetation over the Amazon forest: a model sensitivity study, Atmos. Chem. Phys., 15, 2791-2804, https://doi.org/10.5194/acp-15-2791-2015, 2015.

Paoletti, E., Grulke, N. E., and Matyssek, R.: Ozone Amplifies Water Loss from Mature Trees in the Short Term But Decreases It in the Long Term, Forests, 11, 46, https://doi.org/10.3390/f11010046, 2019.

Pope, R. J., Arnold, S. R., Chipperfield, M. P., Reddington, C. L., Butt, E. W., Keslake, T. D., Feng, W., Latter, B. G., Kerridge, B. J., and Siddans, R.: Substantial increases in Eastern Amazon and Cerrado biomass burning-sourced tropospheric ozone, Geophys. Res. Lett., 47, e2019GL084143, https://doi.org/10.1029/2019GL084143, 2020.

Sadiq, M., Tai, A. P. K., Lombardozzi, D., and Val Martin, M.: Effects of ozone-vegetation coupling on surface ozone air quality via biogeochemical and meteorological feedbacks, Atmos. Chem. Phys., 17, 3055-3066, https://doi.org/10.5194/acp-173055-2017, 2017.

Schiferl, L. D. and Heald, C. L.: Particulate matter air pollution may offset ozone damage to global crop production, Atmos. Chem. Phys., 18, 5953-5966, https://doi.org/10.5194/acp18-5953-2018, 2018.

Sitch, S., Cox, P. M., Collins, W. J., and Huntingford, C.: Indirect radiative forcing of climate change through ozone effects on the land-carbon sink, Nature, 448, 791-794, https://doi.org/10.1038/nature06059, 2007.

Spitters, C.: Separating the diffuse and direct component of global radiation and its implications for modeling canopy photosynthesis Part II. Calculation of canopy photosynthesis, Agr. Forest Meteorol., 38, 231-242, 1986.

Travis, K. R., Jacob, D. J., Fisher, J. A., Kim, P. S., Marais, E. A., Zhu, L., Yu, K., Miller, C. C., Yantosca, R. M., Sulprizio, M. P., Thompson, A. M., Wennberg, P. O., Crounse, J. D., St. Clair, 
J. M., Cohen, R. C., Laughner, J. L., Dibb, J. E., Hall, S. R., Ullmann, K., Wolfe, G. M., Pollack, I. B., Peischl, J., Neuman, J. A., and Zhou, X.: Why do models overestimate surface ozone in the Southeast United States?, Atmos. Chem. Phys., 16, 1356113577, https://doi.org/10.5194/acp-16-13561-2016, 2016.

Turetsky, M. R., Kane, E. S., Harden, J. W., Ottmar, R. D., Manies, K. L., Hoy, E., and Kasischke, E. S.: Recent acceleration of biomass burning and carbon losses in Alaskan forests and peatlands, Nat. Geosci., 4, 27-31, https://doi.org/10.1038/Ngeo1027, 2011.

Val Martin, M., Logan, J. A., Kahn, R. A., Leung, F.-Y., Nelson, D. L., and Diner, D. J.: Smoke injection heights from fires in North America: analysis of 5 years of satellite observations, Atmos. Chem. Phys., 10, 1491-1510, https://doi.org/10.5194/acp10-1491-2010, 2010.

van der Werf, G. R., Randerson, J. T., Giglio, L., Collatz, G. J., Mu, M., Kasibhatla, P. S., Morton, D. C., DeFries, R. S., Jin, Y., and van Leeuwen, T. T.: Global fire emissions and the contribution of deforestation, savanna, forest, agricultural, and peat fires (1997-2009), Atmos. Chem. Phys., 10, 11707-11735, https://doi.org/10.5194/acp-10-11707-2010, 2010.

Von Caemmerer, S. and Farquhar, G. D.: Some relationships between the biochemistry of photosynthesis and the gas exchange of leaves, Planta, 153, 376-387, 1981.

Vongruang, P., Wongwises, P., and Pimonsree, S.: Assessment of fire emission inventories for simulating particulate matter in Upper Southeast Asia using WRF-CMAQ, Atmos. Pollut. Res., 8, 921-929, https://doi.org/10.1016/j.apr.2017.03.004, 2017.

Wang, X., Parisien, M. A., Taylor, S. W., Perrakis, D. D., Little, J., and Flannigan, M. D.: Future burn probability in southcentral British Columbia, Int. J. Wildl. Fire, 25, 200-212, https://doi.org/10.1071/WF15091, 2016.

Watson, G. L., Telesca, D., Reid, C. E., Pfister, G. G., and Jerrett, M.: Machine learning models accurately predict ozone exposure during wildfire events, Environ. Pollut., 254, 112792, https://doi.org/10.1016/j.envpol.2019.06.088, 2019.

Wiedinmyer, C., Akagi, S. K., Yokelson, R. J., Emmons, L. K., AlSaadi, J. A., Orlando, J. J., and Soja, A. J.: The Fire INventory from NCAR (FINN): a high resolution global model to estimate the emissions from open burning, Geosci. Model Dev., 4, 625641, https://doi.org/10.5194/gmd-4-625-2011, 2011.

Wittig, V. E., Ainsworth, E. A., Naidu, S. L., Karnosky, D. F., and Long, S. P.: Quantifying the impact of current and future tropospheric ozone on tree biomass, growth, physiology and biochemistry: a quantitative meta-analysis, Glob. Change Biol., 15, 396424, https://doi.org/10.1111/j.1365-2486.2008.01774.x, 2009.

Yan, Y., Lin, J., and He, C.: Ozone trends over the United States at different times of day, Atmos. Chem. Phys., 18, 1185-1202, https://doi.org/10.5194/acp-18-1185-2018, 2018.
Yue, X. and Unger, N.: Ozone vegetation damage effects on gross primary productivity in the United States, Atmos. Chem. Phys., 14, 9137-9153, https://doi.org/10.5194/acp-149137-2014, 2014.

Yue, X. and Unger, N.: The Yale Interactive terrestrial Biosphere model version 1.0: description, evaluation and implementation into NASA GISS ModelE2, Geosci. Model Dev., 8, 2399-2417, https://doi.org/10.5194/gmd-8-2399-2015, 2015.

Yue, $X$. and Unger, N.: Fire air pollution reduces global terrestrial productivity, Nat. Commun., 9, 5413, https://doi.org/10.1038/s41467-018-07921-4, 2018.

Yue, X., Mickley, L. J., Logan, J. A., Hudman, R. C., Martin, M. V., and Yantosca, R. M.: Impact of 2050 climate change on North American wildfire: consequences for ozone air quality, Atmos. Chem. Phys., 15, 10033-10055, https://doi.org/10.5194/acp-1510033-2015, 2015.

Yue, X., Keenan, T. F., Munger, W., and Unger, N.: Limited effect of ozone reductions on the 20-year photosynthesis trend at Harvard forest, Glob. Change Biol., 22, 3750-3759, https://doi.org/10.1111/gcb.13300, 2016.

Yue, X., Strada, S., Unger, N., and Wang, A.: Future inhibition of ecosystem productivity by increasing wildfire pollution over boreal North America, Atmos. Chem. Phys., 17, 13699-13719, https://doi.org/10.5194/acp-17-13699-2017, 2017.

Zhang, L., Jacob, D. J., Downey, N. V., Wood, D. A., Blewitt, D., Carouge, C. C., van Donkelaar, A., Jones, D. B., Murray, L. T., and Wang, Y.: Improved estimate of the policy-relevant background ozone in the United States using the GEOS-Chem global model with $1 / 2 \times 2 / 3$ horizontal resolution over North America, Atmos. Environ., 45, 6769-6776, 2011.

Zhou, S. S., Tai, A. P. K., Sun, S., Sadiq, M., Heald, C. L., and Geddes, J. A.: Coupling between surface ozone and leaf area index in a chemical transport model: strength of feedback and implications for ozone air quality and vegetation health, Atmos. Chem. Phys., 18, 14133-14148, https://doi.org/10.5194/acp-18-141332018, 2018.

Zhu, J., Tai, A. P. K., and Yim, S. H. L.: Effects of ozone-vegetation interactions on meteorology and air quality in China using a twoway coupled land-atmosphere model, Atmos. Chem. Phys. Discuss. [preprint], https://doi.org/10.5194/acp-2021-165, in review, 2021.

Ziemke, J. R., Chandra, S., Duncan, B. N., Schoeberl, M. R., Torres, O., Damon, M. R., and Bhartia, P. K.: Recent biomass burning in the tropics and related changes in tropospheric ozone, Geophys. Res. Lett., 36, L15819, https://doi.org/10.1029/2009GL039303, 2009. 